\title{
Pengaruh Proses Penggorengan Terhadap Kandungan Nitrit dalam Kornet
}

\author{
Effect of Frying Process on Nitrite Content of Corned
}

\author{
Handaru Bowo Cahyono ${ }^{1}$ \\ Balai Riset dan Standardisasi \\ Industri Surabaya \\ Jl. Jagir Wonokromo No. 360 \\ Surabaya, Jawa Timur, Indonesia
}

\author{
Rieke Yuliastuti ${ }^{2}$ \\ Balai Riset dan Standardisasi \\ Industri Surabaya \\ Jl. Jagir Wonokromo No. 360 \\ Surabaya, Jawa Timur, Indonesia \\ riekeyuliastuti@yahoo.com
}

\author{
Lutfi Amanati ${ }^{3}$ \\ Balai Riset dan Standardisasi \\ Industri Surabaya \\ Jl. Jagir Wonokromo No. 360 \\ Surabaya, Jawa Timur, Indonesia
}

\begin{abstract}
Abstrak - Nitrit merupakan bahan tambahan pangan (BTP) dalam produksi kornet yang berfungsi sebagai pemberi warna dan penghambat bakteri namun jumlahnya dibatasi sehingga penting untuk dilakukan penelitian mengenai pengaruh proses penggorengan terhadap kandungannya. Dari hasil penelitian yang dilakukan dengan suhu penggorengan $100^{\circ} \mathrm{C}, 125^{\circ} \mathrm{C}$, $185^{\circ} \mathrm{C}$ dan lama penggorengan $0,5,10,15$ menit maka dihasilkan penurunan nitrit dari $28-70 \%$ dimana semakin tinggi suhu dan lama penggorengan maka semakin tinggi penurunan nitrit. Dari hasil perhitungan Acceptable Daily Intake (ADI), maka nitrit yang tersisa masih aman dikonsumsi pada sampel anak anak dengan berat badan $17 \mathrm{~kg}$ adalah maksimal 50 gram/hari.
\end{abstract}

Kata Kunci — kornet, nitrit, penggorengan, ADI

Abstract - Nitrite is a food additives (BTP) in corned beef production that functions as a colorizer and a bacterial inhibitor but the amount is limited so it is important to do research on the effect of the frying process on the womb. From the results of the research carried out with a temperature of $100^{\circ} \mathrm{C}, 125^{\circ} \mathrm{C}, 185^{\circ} \mathrm{C}$ and a length of frying 0, 5, 10, 15 minutes the nitrite reduction was from 28-70\% where the higher the temperature and length of the frying the higher the nitrite reduction. From the calculation of the Acceptable Daily Intake (ADI), the remaining nitrite is still safe for consumption in a sample of children weighing $17 \mathrm{~kg}$ is a maximum of 50 grams / day.

Keywords - cornet, nitrite, frying, ADI.

\section{PENDAHULUAN}

Corned Beef atau Kornet, adalah salah satu jenis produk olahan daging sapi yang banyak digunakan dalam resep masakan Indonesia. Kornet daging sapi diolah dengan cara diawetkan dalam air garam (brine), yaitu air yang dicampur dengan larutan garam jenuh. Kemudian dimasak dengan cara simmering, yaitu direbus dengan api kecil untuk menghindari hancurnya tekstur daging sapi. Kornet ini banyak digunakan secara luas dalam resep masakan di Indonesia seperti perkedel, omelet, campuran dalam mie instan, rolade, $\mathrm{dll}^{[1]}$. Tujuan pembuatan kornet daging sapi adalah untuk tetap dapat memperoleh produk daging sapi yang berwarna merah, awet dan praktis dengan ini masalah penyimpanan daging sapi segar dapat diatasi. Agar awet, daging sapi segar harus disimpan pada suhu dingin atau suhu beku.

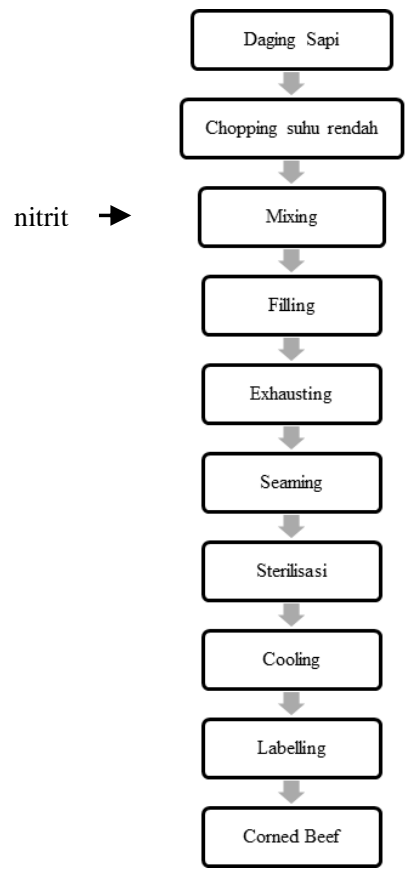

Gambar 1 Proses Pembuatan Kornet

Sesuai dengan gambar diatas, proses pembuatan kornet daging sapi diawali dengan proses penggilingan dengan chopper pada suhu rendah sehingga selama penggilingan, suhu dapat dipertahankan tetap di bawah $16^{\circ} \mathrm{C}$. Hal tersebut dilakukan dengan menambahkan es batu atau air dingin. Hasil gilingan berupa daging cincang yang masih kasar. Setelah dicincang, daging dimasukkan ke 
dalam mixer untuk dicampur dengan bumbu, bahan lain dan ditambahkan nitrit sehingga menjadi adonan yang homogen. Emulsi daging yang telah terbentuk selanjutnya diisikan ke dalam kaleng yang sebelumnya telah disterilkan dengan panas. Pengisian dilakukan dengan menyisakan sedikit ruang kosong di dalam kaleng, disebut head space. Kaleng yang telah diisi, kemudian divakum (exhausting). Setelah keluar dari exhauster box, kaleng dalam keadaan panas langsung ditutup kemudian disterilisasi dan dimasak pada suhu $120^{\circ} \mathrm{C}$ dan tekanan $0,55 \mathrm{~kg} / \mathrm{cm}$. Setelah itu segera didinginkan di dalam bak pendingin yang berisi air. Setelah itu permukaan kaleng dibersihkan dengan lap hingga kering, produk siap untuk diberi label dan dikemas ${ }^{[2]}$.

Bahan dasar pembuatan kornet adalah daging sapi yang digiling. Namun saat ini kornet tidak hanya berasal dari daging sapi namun kornet dari daging ayam juga telah mulai banyak dipasarkan. Daging tersebut kaya protein yang mempunyai kemampuan untuk mengikat air dan membentuk emulsi yang baik. Bahan tambahan yang diperlukan adalah garam dapur, nitrit, alkali fosfat, bahan pengisi, air, lemak, gula, dan bumbu.

Nitrit adalah suatu bahan berwarna putih sampai kekuningan, berbentuk bubuk atau granular dan tidak berbau. Berat jenisnya $2,17\left(25^{\circ} \mathrm{C}\right) \mathrm{g} / \mathrm{mL}$ dengan kelarutan dalam air sebesar $820 \mathrm{~g} / \mathrm{L}\left(20^{\circ} \mathrm{C}\right)$ dan bersifat alkali ( $\left.\mathrm{pH} 9\right)$. Titik leleh sodium nitrit $271-281{ }^{\circ} \mathrm{C}$, titik didih $320{ }^{\circ} \mathrm{C}$, suhu bakar $510{ }^{\circ} \mathrm{C}$, dan suhu penguraian $>320^{\circ} \mathrm{C}$. Natrium nitrit atau Sodium nitrit memiliki kerapatan 2,168 g/cm dan berat molekul 69,0 g/mol ${ }^{[3]}$. Nitrit sebagai Bahan Tambahan Pangan (BTP) berfungsi sebagai penstabil warna merah daging, membentuk flavor yang khas, menghambat pertumbuhan bakteri pembusuk dan beracun, serta memperlambat terjadinya ketengikan (pengawet). Kemampuan nitrit dalam mempertahankan warna merah daging adalah dengan cara bereaksi dengan pigmen mioglobin (pemberi warna merah daging) membentuk nitrosomioglobin berwarna merah cerah yang bersifat stabil $^{[2]}$. Umumnya nitrit tersebut ditambahkan dalam bentuk natrium nitrit. Natrium nitrit atau Sodium Nitrit adalah senyawa nitrogen yang reaktifdan bersifat. Karsinogen pada tubuh sehingga menyebabkan penyakit kanker

Survey yang dilakukan oleh Sugiarti dkk, menyatakan dari 53 sampel daging olahan yang diperiksa 50 $(94,33 \%)$ sampel mengandung nitrit dan $3(5,67 \%)$ sampel tidak mengandung nitrit. Dari hasil penelitiannya diperoleh informasi bahwa kadar natrium nitrit tertinggi sebesar $19,408 \mathrm{mg} / \mathrm{kg}$ dengan rata- rata sebesar $11,249 \mathrm{mg} / \mathrm{kg}$, dan terendah $1,606 \mathrm{mg} / \mathrm{kg}^{[4]}$. Hal yang sama dilakukan oleh Asep. A.S., dkk dimana mereka juga melakukan survey pasar dan memeriksa kandungan nitrit terhadap produk kornet dan sosis yang ternyata memang positip mengandung senyawa nitrit ${ }^{[5]}$. Kandungan nitrit yang dianalisa tersebut adalah dalam kornet yang belum diolah. Terdapat berbagai macam pengolahan kornet diataranya digoreng. Bila dibandingkan dengan sifat titik leleh sodium nitrit, maka akan terdapat penurunan nitrit bila dipanaskan akan tetapi efisiensi penurunannya perlu dilakukan kajian lebih lanjut sehingga dapat diketahui angka keamanannya untuk dikonsumsi.

Dalam ijin penggunaanya, Pemerintah R.I melalui Peraturan Kepala Badan Pengawas Obat Dan Makanan Republik Indonesia Nomor 36 Tahun 2013, Tanggal 22 Mei 2013 Tentang Batas Maksimum Penggunaan Bahan Tambahan Pangan Pengawet, telah mengatur penggunaan nitrit sebagai BTP dimana batas aman penggunaan Natrium nitrit yaitu dibawah $30 \mathrm{mg} / \mathrm{kg}^{[6]}$.Selain membatasi jumlah BTP, Peraturan Kepala Badan Pengawas Obat Dan Makanan Republik Indonesia Nomor 36 Tahun 2013, Tanggal 22 Mei 2013 Tentang Batas Maksimum Penggunaan Bahan Tambahan Pangan Pengawet juga telah memberikan batasan maksimum bahan boleh dikonsumsi setiap hari yang dikenal dengan ADI. ADI (Acceptable Daily Intake) atau asupan harian yang dapat diterima adalah jumlah maksimum bahan tambahan pangan dalam miligram per kilogram berat badan yang dapat dikonsumsi setiap hari selama hidup tanpa menimbulkan efek merugikan terhadap kesehatan. ADI untuk Kalium nitrit dan Sodium nitrit adalah $0-0,06 \mathrm{mg} / \mathrm{kg}$ berat badan ${ }^{[6]}$.

Adanya nitrit dalam kornet yang akan menimbulkan potensi apabila berlebih maka diperlukan suatu penelitian untuk mengetahui apakah jumlah kornet yang beredar dipasaran aman dan nantinya apabila kornet tersebut diolah, nitrit yang terkandung didalamnya akan turun kadarnya. Sehingga tujuan penelitian adalah untuk mengetahui apakah nitrit yang terkandung dalam kornet goreng masih aman dikonsumsi setelah digoreng. Artikel ini menyampaikan hasil kerja tentang potensi penurunan kadar nitrit pada produk kornet akibat proses penggorengan. Suhu dan lama penggorengan menjadi parameter yang digunakan sebagai variabel proses terhadap kandungan nitrit. Kornet dari daging sapi dan minyak sawit dipilih untuk tujuan penelitian ini.

\section{MetOdOLOGI}

Bahan :

Kornet Ayam dan Sapi

Minyak Goreng

Bahan Kimia Untuk Pengujian Nitrit

Alat :

Penggoreng

Buret Untuk Titrasi

Tahapan Penelitian :

Penelitian dilakukan di laboratorium pengujian Baristand Industri Surabaya. Penelitian dilakukan dalam 3 tahapan. 


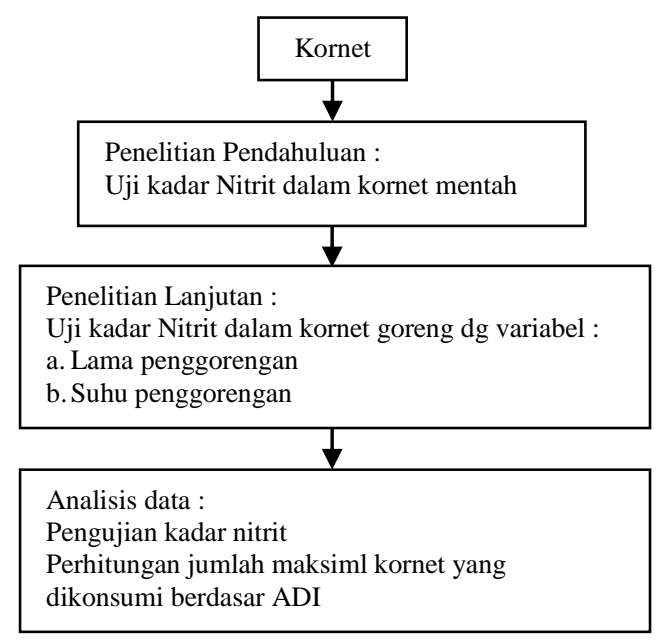

1. Tahap penelitian pendahuluan.

Metode :

Persiapan bahan dilakukan dengan penyesuaian temperatur sampel sesuai dengan suhu ruang. Sampel dicacah kecil-kecil kemudian dicampur jadi satu selanjutnya diambil secara acak untuk diuji kadar nitritnya. Kornet daging sapi dipersiapkan untuk penelitian lebih lanjut, namun kornet daging ayam tidak diteliti lebih lanjut.

2. Tahap penelitian lanjutan.

Metode :

Pada tahapan ini kornet dibentuk pipih dengan bobot sekitar 50 gram dan selanjutnya kornet digoreng dalam minyak goreng sawit yang telah dipersiapkan. Metode pemasakan kornet dipilih dengan cara digoreng adalah cara mudah, prektis dan banyak digemari.

Variabel bebas yang digunakan adalah :

a. Durasi penggorengan (menit) : $0,5,10,15$

b. Temperatur penggorengan $\left({ }^{\circ} \mathrm{C}\right): 100,125,185$

3. Analisa Hasil

a. Pada Tahap Pengujian kadar nitrit, kornet yang akan dianalisa dilarutkan ke air kemudian dianalisa menggunakan metode kolorimetri dimana berdasarkan pembentukan warna kemerahmerahan dari reaksi nitrit dengan asam sulfanilat dan $\mathrm{N}$-(1-naftil etilen diamin dihidroklorida) pada $\mathrm{pH} 2$ sampai $\mathrm{pH}$ 2,5. Pembacaan dilakukan dengan spektrofotometer panjang gelombang 573.

b. Setelah didapatkan hasil analisa nitrit, maka dihitung Acceptable Daily Intake (ADI) kemudian hasilnya dibandingkan kesesuaiannya dengan Batas Maksimum Penggunaan Bahan Tambahan Pangan Pengawet untuk nitrit dalam Peraturan Kepala Badan Pengawas Obat Dan Makanan Republik Indonesia Nomor 36 Tahun 2013, Tanggal 22 Mei 2013. Dari perbandingan tersebut maka dapat diketahui banyak kornet yang boleh dikonsumsi berdasarkan berat badan konsumen. Adapun perhitungan ADI sesuai dengan rumus berikut:

$$
\mathrm{ADI}=\frac{\frac{\mathrm{a}}{1000} \times \mathrm{b}}{\mathrm{c}}
$$

Dimana

$$
\begin{aligned}
& \text { a : banyak kornet yang dikonsumsi (gram) } \\
& \mathrm{b}: \text { jumlah nitrit }(\mathrm{mg} / \mathrm{kg}) \\
& \mathrm{c} \text { : berat badan konsumen }(\mathrm{kg})
\end{aligned}
$$

\section{HASIL DAN PEMBAHASAN}

Dari hasil pengamatan pada kemasan produk informasi yang diberikan produsen antara lain terkait jenis produk kornet daging ayam atau daging sapi, merek dagang, berat netto, produsen dan alamat produsen, bahan penyusun kornet antara lain : bahan utama yaitu daging ayam atau sapi, bumbu, gula, garam, penguat rasa dan bahan pengawet. Bahan pengawet yang digunakan umumnya adalah Sodium nitrit $\left(\mathrm{NaNO}_{2}\right)$ namun pada umumnya tidak ada informasi mengenai jumlah atau kadarnya untuk masing-masing bahan penyusun. Informasi lain yang dicantumkan pada label kemasan adalah masa simpan / expired date produk. Produk kornet dikemas dalam kemasan plastik dan kaleng logam.

Dari hasil pengujian kadar nitrit pada beberapa produk kornet yang beredar di pasaran Surabaya diperoleh data sebagai berikut :

TABEL 1. KANDUNGAN NITRIT PADA BEBERAPA JENIS KORNET

\begin{tabular}{|c|l|c|c|}
\hline No & Jenis Kornet & Merek & $\begin{array}{c}\text { Kadar Nitrit } \\
(\mathrm{mg} / \mathrm{kg})\end{array}$ \\
\hline 1 & Daging Ayam & A & 13,53 \\
\hline 2 & Daging Ayam & B & 24,61 \\
\hline 3 & Daging Sapi & C & 17,71 \\
\hline 4 & Daging Sapi & D & 25,57 \\
\hline
\end{tabular}

Dari data pada tabel 1 diatas maka terlihat bahwa pada semua jenis kornet mengandung nitrit dengan rentang kadar nitrit yang ditambahkan bervariatif namunmasih dibawah ambang batas yang diijinkan oleh PerkaBPOM Nomor 36 Tahun 2013 yaitu $30 \mathrm{mg} / \mathrm{kg}$.

Fungsi senyawa nitrit dalam produk olahan daging tersebut diinformasikan sebagai bahan pengawet lebih menonjol walaupun sebenarnya senyawa nitrit juga mampu berfungsi sebagai fiksatif warna daging. Sebagai pengawet bahan pangan khususnya produk olehan daging, nitrit akan menghambat pertumbuhan bakteri Clostridium botulinum yang berpotensi mengakibatkan keracunan bahkan kematian $^{[7]}$. 
Kornet dianjurkan selalu disimpan dalam kondisi beku sehingga diperlukan penanganan sebelum kornet dapat dihidangkan. Proses pemasakan kornet sebelum dihidangkan sebagai bahan pangan adalah salah satu metoda untuk mendapatkan produk pangan yang lebih hygienis dan tidak terkontaminasi mikroorganisme patogenik sehingga aman untuk dikonsumsi. Metoda penggorengan dipilih dalam penelitian ini karena merupakan salah satu cara menghidangkannya adalah di goreng karena praktis, mudah dalam pengerjaannya dan popular dimasyarakat. Metoda lain yang serupa adalah dikukus yaitu pemasakan dengan menggunakan steam atau uap air panas dengan produk misalnya adalah rolade.

Selanjutnya untuk mengetahui pengaruh penggorengan terhadap sifat nitrit dalam kornet maka dilakukan penelitian dengan beberapa variasi suhu $\left(100^{\circ} \mathrm{C}\right.$, $\left.125^{\circ} \mathrm{C}, 185^{\circ} \mathrm{C}\right)$ dan lama penggorengan $(0$ menit, 5 menit, 10 menit, 15 menit) dan didapatkan hasil sebagai berikut :

TABEL 2. KADAR NITRIT PADA KORNET SETELAH DIGORENG DENGAN SUHU $100^{\circ} \mathrm{C}$

\begin{tabular}{|c|c|c|}
\hline Kode & $\begin{array}{c}\text { Lama } \\
\text { penggorengan } \\
\text { (menit) }\end{array}$ & $\begin{array}{c}\text { Kadar Nitrit } \\
\mathrm{mg} / \mathrm{kg}\end{array}$ \\
\hline $\mathrm{A} 0$ & 0 & 25,70 \\
\hline $\mathrm{A} 1$ & 5 & 18,50 \\
\hline $\mathrm{A} 2$ & 10 & 16,33 \\
\hline $\mathrm{A} 3$ & 15 & 9,35 \\
\hline
\end{tabular}

TABEL 3. KADAR NITRIT PADA KORNET SETELAH DIGORENG DENGAN SUHU $125^{\circ} \mathrm{C}$

\begin{tabular}{|l|c|c|}
\hline Kode & $\begin{array}{c}\text { Lama } \\
\text { penggorengan } \\
\text { (menit) }\end{array}$ & $\begin{array}{c}\text { Kadar Nitrit } \\
\mathrm{mg} / \mathrm{kg}\end{array}$ \\
\hline B0 & 0 & 25,70 \\
\hline B1 & 5 & 12,45 \\
\hline B2 & 10 & 11,62 \\
\hline B3 & 15 & 8,92 \\
\hline
\end{tabular}

TABEL 4. KADAR NITRIT PADA KORNET SETELAH DIGORENG DENGAN SUHU $185^{\circ} \mathrm{C}$

\begin{tabular}{|l|c|c|}
\hline Kode & $\begin{array}{c}\text { Lama } \\
\text { penggorengan } \\
\text { (menit) }\end{array}$ & $\begin{array}{c}\text { Kadar Nitrit } \\
\mathrm{mg} / \mathrm{kg}\end{array}$ \\
\hline $\mathrm{C} 0$ & 0 & 25,70 \\
\hline $\mathrm{C} 1$ & 5 & 9,64 \\
\hline $\mathrm{C} 2$ & 10 & 8,56 \\
\hline $\mathrm{C} 3$ & 15 & 7,82 \\
\hline
\end{tabular}

Dari tabel di atas terlihat bahwa proses penggorengan produk kornet daging sapi berpengaruh terhadap penurunan kadar nitrit dalam kornet. Hal tersebut terjadi di semua perlakuan suhu pengorengan yaitu suhu $100^{\circ} \mathrm{C}, 125^{\circ} \mathrm{C}$ dan $185^{\circ} \mathrm{C}$. Hal ini disebabkan karena proses transfer massa / difusi molekuler dimana senyawa senyawa nitrit yang berkonsentrasi tinggi di dalam produk kornet kemudian akan merembes keluar menuju media minyak goreng.Sejalan dengan penelitian yang dilakukan oleh
Merino et all yang mengemukakan bahwa proses penggorengan akan menurunkan kadar nitri hingga lebih dari $50 \%$ sedangkan pengolahan kornet dengan proses pengukusan bisa jadi tidak berpengaruh terhadap penurunan nitrit $^{[8]}$.

Analisis yang terjadi terhadap pengurangan nitrit yaitu terdapat dua hal yaitu :

a. Terdapat perpindahan nitrit dari kornet ke minyak goreng dan terdapat pelepasan nitrit ke udara.

Proses penggorengan, kornet yang digoreng dengan minyak goreng sawit akan berkontak langsung dengan media dengan volume yang banyak (bahan terapung pada minyak goreng) dan dalam suhu sekitar $100^{\circ} \mathrm{C}$ minyak goreng telah mampu menunjukkan fungsinya sebagai media pemasak. Minyak goreng sawit memiliki temperature didih kisaran 160 hingga $200 \mathrm{C}$, namun pada suhu sekitar $100 \mathrm{C}$ minyak goreng telah mampu melepaskan air atau kadar air bahan yang bersentuhan dengannya dengan indikasi timbulnya gelembung udara yang keluar dari bahan basah yang bersentuhan dengannya yaitu terurainya senyawa $\mathrm{H}_{2} \mathrm{O}$ menjadi $\mathrm{H}_{2}$ gas dan $\mathrm{O}_{2}$ gas. Lepasnya air dari dalam produk kornet akan membawa sebagian Sodium nitrit dari dalam kornet menuju minyak goreng. Hal ini karena Sodium nitrit memiliki kelarutan yang sangat tinggi pada air sehingga ketika air mulai bergerak secara bertahap dari bagian terdalam bahan yang digoreng menuju bagian yang lebih terluar maka sodium nitrit juga akan turut terbawa hingga sebagian terlepas dan terjadi perpindahan ke media minyak goreng. Pengukuran dilakukan di produk akhir yang telah digoreng dimana terbukti terjadi penurunan nitrit.

b. Adanya peningkatan suhu penggorengan juga berpengaruh terhadap penurunan nitrit.

Semakin tinggi suhu penggorengan, maka penurunan kadar nitrit dalam produk kornet juga semakin tinggi. Hal ini dikarenakan bahwa viskositas minyak goreng yang semakin rendah dengan semakin meningkatnya temperature pemanasan sehingga semakin mempermudah setiap bagian minyak goreng bersentuhan langsung dengan produk kornet secara bergantian per satuan waktu. Dengan artian makin panas suhunya maka viskositas minyak goreng akan makin rendah sehingga secara visual akansemakin encer. Pada saat tersebut maka Sodium nitrit akan berpindah dari tempat berkonsentrasi tinggi (kornet) ke tempat yang konsentrasi sodium nitritnya rendah (minyak goreng).

Adapun prosentase penurunan nitrit dapat dilihat pada gambar 1 berikut, 


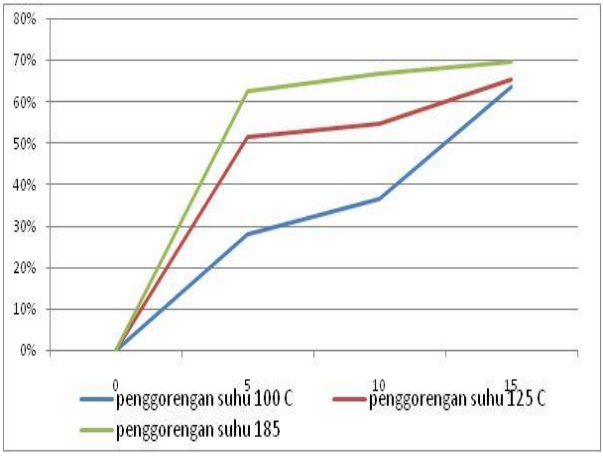

Gambar 1 Prosentase Penurunan Nitrat

Dari gambar grafik di atas tampak bahwa terjadi penurunan kadar nitrit di semua perlakuan suhu penggorengan kornet yaitu suhu $100^{\circ} \mathrm{C} ; 125^{\circ} \mathrm{C}$ dan suhu $185^{\circ} \mathrm{C}$. Namun tampak bahwa pada perlakuan pemansan pada suhu $185^{\circ} \mathrm{C}$ terjadi penurunan kadar nitrit paling tinggi untuk semua durasi waktu penggorengan $(5,10,15$ menit) dengan nilai paling tinggi mencapai $69,56 \%$ dengan sisa nitrit pada produk kisaran $7,82 \mathrm{mg} / \mathrm{kg}$ pada durasi penggorengan selama 15 menit. Namun demikian secara visual, pada produk telah menunjukkan hasil yang kurang bagus karena sudah tampak mulai menghitam sehingga bisa dikatakan durasi penggorengan lebih dari 15 menit tidak disarankan karena produk hangus.

Penurunan kadar nitrit telah tampak meningkat tajam pada durasi penggorengan menit ke 5 dan 10 dengan gambaran mulai melandai pada durasi penggorengan selama 5 menit dan 10 menit untuk semua perlakuan suhu penggorengan. Pada perlakuan penggorengan dengan temperature $125^{\circ}$ dan $185^{\circ} \mathrm{C}$ tidak tampak lagi peningkatan removal yang menonjol.

Dari tabel 2 sampai dengan tabel 4 dapat diamati bahwa setelah proses penggorengan maka kadar nitrit dalam produk kornet daging sapi secara umum telah mengalami penurunan dengan rentang sisa antara 7,82 hingga 18,50 $\mathrm{mg} / \mathrm{kg}$ dari kadar awal sebanyak 25,70 mg/ kg. Menurut PerkaBPOM Nomor 36 Tahun 2013, tanggal 22 Mei 2013 Tentang Batas Maksimum PenggunaanBahan Tambahan Pangan Pengawet telah ditetapkan batasan maksimum bahan boleh dikonsumsi setiap hari yang dikenal dengan ADI untuk Kalium nitrit dan Sodium nitrit adalah $0-0,06 \mathrm{mg} / \mathrm{kg}$ berat badan. Sehingga untuk kornet daging sapi sebagai obyek penelitian ini dapat dihitung sebagai berikut :

- Nitrit sisa terbesar $=18,50 \mathrm{mg} / \mathrm{kg}$

Berat daging yang dikonsumsi $=50$ gram asumsi berat badan konsumen $=65 \mathrm{~kg}$

Maka ADI $=\frac{\frac{50}{1000} \times 18,50}{65}=0,014 \mathrm{mg} / \mathrm{kg}$

Disini dikategorikan nitrit yang terkandung aman dikonsumsi karena ADI $<0,06$

Dengan perhitungan sama, dilakukan simulasi perhitungan ADI untuk berat badan usia anak-anak pada tabel 4 berikut.

TABEL 5. PERHITUNGAN ADI KORNET UNTUK ANAK

\begin{tabular}{|c|c|c|}
\hline No & Berat Badan $(\mathrm{kg})$ & $\begin{array}{c}\mathrm{ADI} \\
(\mathrm{mg} / \mathrm{kg})\end{array}$ \\
\hline 1 & 20 & 0,05 \\
\hline 2 & 19 & 0,05 \\
\hline 3 & 18 & 0,05 \\
\hline 4 & 17 & 0,05 \\
\hline 5 & 16 & 0,06 \\
\hline 6 & 15 & 0,06 \\
\hline 7 & 14 & 0,07 \\
\hline 8 & 13 & 0,07 \\
\hline
\end{tabular}

Dari tabel 5 terlihat bahwa nitrit sebanyak $18,50 \mathrm{mg} / \mathrm{kg}$ dalam kornet masih aman dikonsumsi untuk anak dengan berat badan $17 \mathrm{~kg}$ asalkan tidak melebihi 50 gram/hari.

\section{KESIMPULAN}

Berdasarkan hasil penelitian, kornet yang beredar di pasar positif mengandung nitrit. Kandungan nitrit tersebut dapat mengalami penurunan oleh aktivitas pengorengan. Penurunan nitrit terhadap temperatur $100^{\circ} \mathrm{C}, 125^{\circ} \mathrm{C}, 185^{\circ} \mathrm{C}$ dan variasi lama penggorengan $0,5,10,15$ menit maka dihasilkan penurunan nitrit dari $28-70 \%$, dimana semakin tinggi suhu dan lama penggorengan maka semakin tinggi penurunan nitrit. Kornet yang mengandung nitrit tersisa masih aman dikonsumsi bila $<50$ gram/hari untuk berat badan diatas $17 \mathrm{~kg}$.

\section{DAFTAR PUSTAKA}

[1] Asep,https://Www.Academia.Edu/7244792/Analisa Kualitatif Kandungan Nitrat Nitrit Dalam Sosis Dan Kornet_Berbagai_Merk, diakses tanggal 07-10-2018

[2] Anonim,2013,http://sanietaraa24.blogspot.com/2013/0 2/kornet-sapi.html), diakses tanggal 08-10-2018

[3] Anonim,2013,http://hfzhemstory.blogspot.com/2013/0 1/dampak-penggunaan-natrium-nitrit 9926.html, diakses tanggal 08-10-2018

[4] Sugiarti, 2014, Gambaran Kadar Nitrit Pada Beberapa Produk Daging Olahan Di Bandar Lampung Tahun 2014, Jurusan Analis Kesehatan Polteknik Kesehatan KemenkesTanjungkarang,https://webcache.googleuser content.com/search?q=cache:ZaCYxYUJ7IcJ:https://ej urnal.poltekkestjk.ac.id/index.php/JANALISKES/articl e/view/423/398+\&cd=13\&hl=id\&ct=clnk\&gl=id

[5] A.Asep, Alami F, Mutia S A, Analisa Kualitatif Kandungan Nitrat - Nitrit Dalam Sosis Dan Kornet Berbagai Merk, Program Studi Kimia Fakultas Sains dan Teknologi UIN Syarif Hidayatullah, https://www.academia.edu/7244792/Analisa_Kualitatif Kandungan_Nitrat_Nitrit_Dalam_Sosis_Dan_Kornet Berbagai_Merk

[6] Peraturan Kepala Badan Pengawas Obat Dan Makanan Republik Indonesia Nomor 36 Tahun 2013, Tanggal 
22 Mei 2013 Tentang Batas Maksimum Penggunaan Bahan Tambahan Pangan Pengawet

[7] Anonim,

http://anahrahmat44artikle.blogspot.com/2013/05/caramenghilangkan-nitrit-dalam-makanan.html, diakses tanggal 20-10-2018

[8] Merino et all, 2016, Time-dependent depletion of nitrit in pork/beef and chicken meat product and its effect on nitrite intake estimation, Food additives \& Contaminants: Part A, Published by Taylor \& Francis, $186-192$ 